formance as a success. This year has been a tremendous learning experience for water districts and farmers alike. The drainage incentive fee imposed on the Grasslands Area farmers for the selenium load overage will be placed in an account. The funds will be directed to projects that will help further reduce selenium drainage.

A unique feature of the Grasslands Bypass Project is the spirit of cooperation between water districts in this novel program. Rather than attempting to legally define each water district's share of the collective selenium discharge target load, the participants have chosen to work as one unit in meeting goals, allowing participating water districts to strive to implement best management practices at their own pace. The advances made in the past 12 months have been an intensive learning experience for water districts and individual growers alike as they seek ways to develop sustainable agronomic techniques that meet environmental policy goals and waterquality objectives for the San Joaquin River.

N.W.T. Quinn is Staff Geological Scientist, Lawrence Berkeley National Laboratory, and Water Resources Engineer, U.S. Bureau of Reclamation, Sacramento; J.C. McGahan is Principal Engineer, Summers Engineering Inc., Hanford; and M.L. Delamore is Chief Drainage Section, U.S. Bureau of Reclamation, Fresno.

\section{Further reading}

Quinn NWT. 1995. A compliance monitoring program for use and operation of the Grasslands Bypass for drainage conveyance in the western San Joaquin Valley. Lawrence Berkeley National Laboratory Topical Report, LBNL-39052, Berkeley, CA 94720.

Quinn NWT, Chen CW, Grober LF, et al 1997. Real-time management of water quality in the San Joaquin River. Cal Ag 51(5):14-20.

Summers Engineering Inc. 1997. Summary of Grassland Basin Drainers Drainage Reduction Activities. Meeting package for Grasslands Bypass project tour.

USBR. 1996. Proposed monitoring program for use and operation of the Grasslands Bypass to remove agricultural drainage from Grassland Water District channels. Sacramento, CA.

\title{
Subsurface drainage systems have little impact on water tables, salinity of clay soils
}

\author{
Mark E. Grismer $\square \quad$ Khaled M. Bali
}

Subsurface drainage systems are traditionally installed in agricultural fields to control waterlogging (high water tables) and excess salinity affecting the crop root zone. However, in many clay fields of the Imperial Valley underlain by shallow fine-sand aquifers, the drains may be ineffective and provide limited relief for the root zone. After extensive work considering soil-water flow paths in a particular field at the UC Desert Research and Extension Center (DREC), we plugged whole-field drainage systems, then evaluated the impact on water-table levels and soil salinity during a 3-year period. We found that the shallow fine-sand aquifer underlying the $D R E C$, originally identified in the 1950s, combined with the Imperial Irrigation District deep-ditch system, provided sufficient drainage relief for several areas of the DREC to successfully grow a variety of crops. Given the ineffectiveness of subsurface drainage systems in three different fields that had soil characteristics similar to more than half the Imperial Valley fields we expect that in many parts of the valley, augmentation of subsurface drainage systems through "splitting" the lateral drainline spacing may not be warranted. Indeed, efforts to reduce the salinity of heavier soils on the DREC, or elsewhere in the valley, may be better directed at improving water penetration and leaching of soils through deep ripping or other cultivation/mulching methods, rather than expending resources on improving the subsurface drainage system.

Subsurface drainage systems are traditionally installed in agricultural fields to control waterlogging (high water tables) and excess salinity affecting the crop root zone. The conceptual basis for such systems is simply to provide an artificial "outlet" for the excess water and salts in the soil resulting from regular irrigation (or from rainfall in humid areas). Although proper identification of the source of the excess water and salinity is important to the design of these systems, in many arid regions that source is assumed to be (and often is) excess irrigation recharge resulting from less-than-perfect application efficiency and distribution uniformity. In some cases, however, a more detailed field investigation may be appropriate to identify other possible sources of excess water and salinity.

We have been investigating the performance of subsurface drainage systems at the UC Desert Research and Extension Center (DREC) for the past three decades to determine their value relative to control of shallow groundwater levels and root-zone soil salinity (Grismer et al. 1988). In the cracking, or heavy clay, soils found on the DREC and in over $40 \%$ of the valley, the drains are relatively ineffective in 


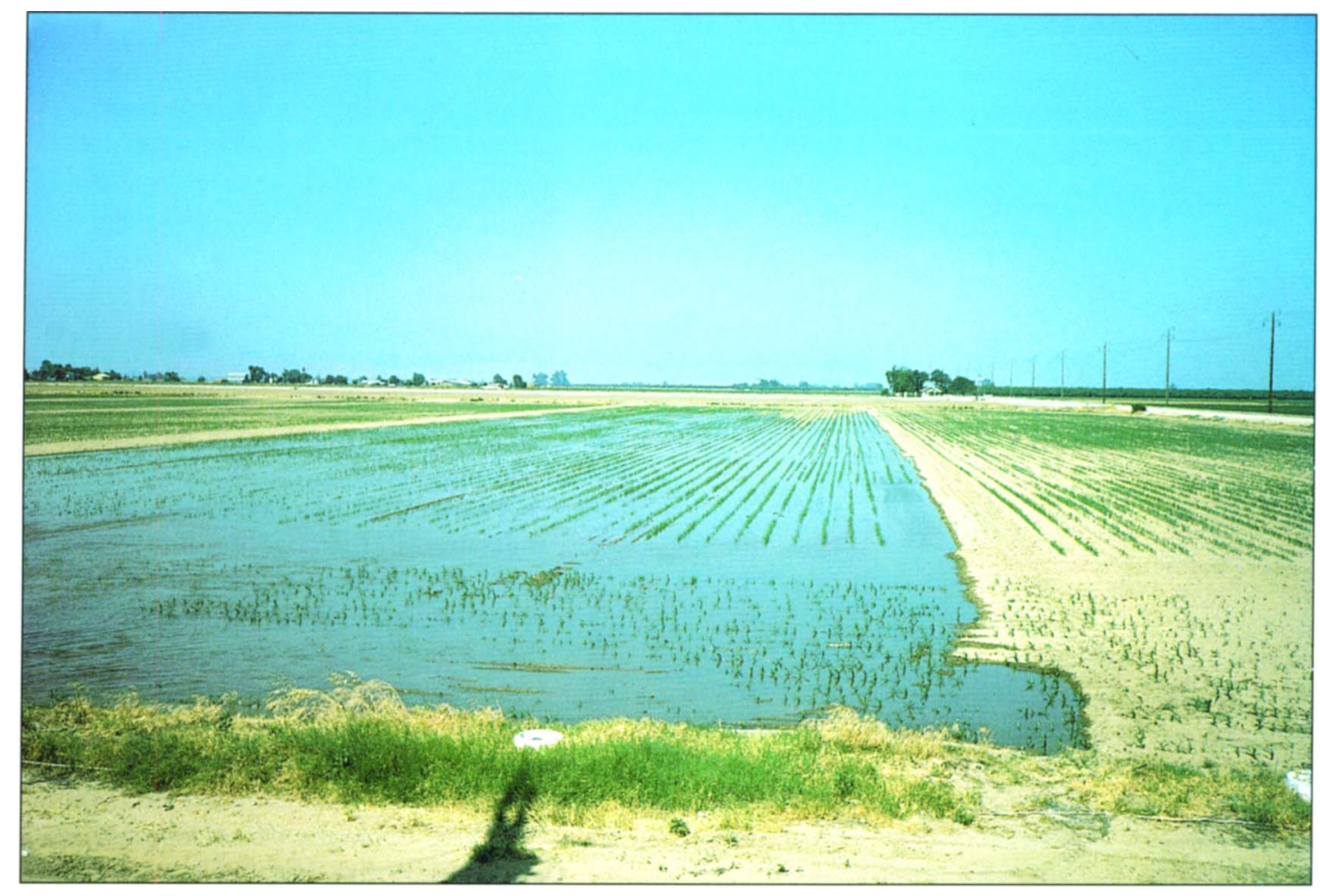

Drainage systems are traditionally installed beneath crop fields to prevent waterlogging and excess salinity in the crop root zone, but deep drainage ditches may be sufficient at many sites.

controlling water-table depth and soil salinity. Their ineffectiveness is due to the presence of a fine-sand aquifer located 6 to 10 feet ( 2 to 3 meters) below the land surface and the slowly permeable nature of the clay soils (Grismer and Tod 1991; Tod and Grismer 1991). The fine-sand aquifer serves as a subsurface drainage reservoir that supplies water and salinity to the root zone via upward flow despite the presence of the drainage lines (Grismer and Gates 1988).

\section{Fine-sand aquifer flows}

Detailed study of the soil-water flow paths near drainlines indicated that immediately following irrigation, drain flows increase quickly due to flow through the back-filled trench (even after 25 years) immediately above the drains. Within a day following irrigation, drain flow rates decrease substantially because they draw soil-water from an effective radius of only 10 feet (about $3 \mathrm{~m}$ ) from the drain and groundwater from the shallow fine-sand aquifer immediately below the fields. Root-zone drainage from excess irrigation at distances greater than a few yards on either side of each drainline moves vertically into this same aquifer rather than flowing laterally toward the drainlines. In fact, in a northwest section (Area 70) of the DREC, over $90 \%$ of the annual drainage flows originate from the fine-sand aquifer rather than root-zone drainage resulting from an irrigation event. Moreover, replacement of 20-year-old clay and bituminous fiber drains with new plastic drains only increased drain flow rates, primarily from increased "trench flows" and greater interception of the shallow aquifer waters rather than improved "drainage" of the field as a whole. The new drains were no more effective in controlling root-zone salinity or water-table depth than the original drains (Grismer et al. 1988). More recently, we have reported on investigations of alternative vertical drainage and leaching techniques to address the problems associated with poor drainage of these clay soils (Yusufzai and Grismer 1994; Grismer and Bali 1997), as well as alternative drainage system design strategies in general (Ayars et al. 1997).

Although we identified the limited effectiveness of specific drains in a heavy clay field, we were interested in the effectiveness of whole drainage systems in nearby fields that had more variable and lighter-textured soils, which were subject to different cropping regimes than the forage crops we planted in Area 70. Our interest was in part motivated by a desire to demonstrate actual fieldwide effectiveness, if any, of the subsurface drainage systems, as well as to obtain insight into the value of installation or augmentation of lateral subsurface drainage systems in the Imperial Valley.

Based on our work in the clay field (Area 70) and DREC-wide identification of the large extent of the shallow finesand aquifer, we hypothesized that the subsurface drainage systems in nearby loamy-textured soils may also be of limited value in terms of water-table and salinity control. The purpose of this study was to determine whether artificial drainage systems were actually effective in controlling water-table depths and salinity in clay loam fields that do not have the fine-sand aquifer within 10 feet of the land surface (Areas 40 and 80 of the DREC). If indeed the artificial drainage systems are not required, it appears that the deep drainage ditches managed by the Imperial Irrigation District (IID) may be sufficient in many cases for watertable and salinity control throughout the valley.

\section{Fieldwork at the DREC}

The fieldwork was conducted from August 1994 to the present in Areas 40 and 80 of the DREC. Both areas are serviced by subsurface drainage systems at an average depth of 6 feet. Area 40 is a rectangular field approximately 1,500 feet long by 600 feet wide, or about 21 acres. It is located on the southeastern corner of the DREC and is the most distant field from Area 


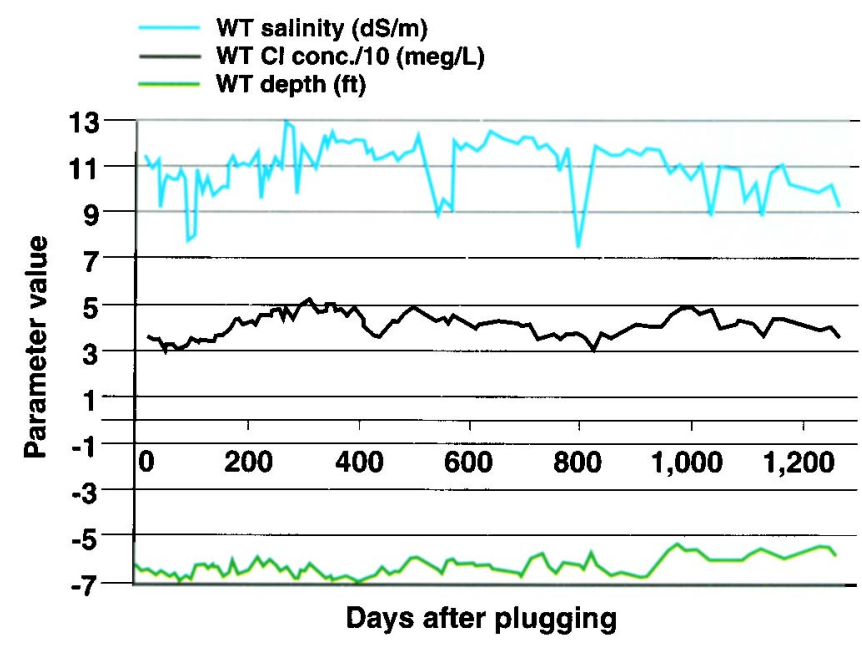

Fig. 1. Area 40 water-table levels, salinity and chloride concentrations after plugging subsurface drainage system.

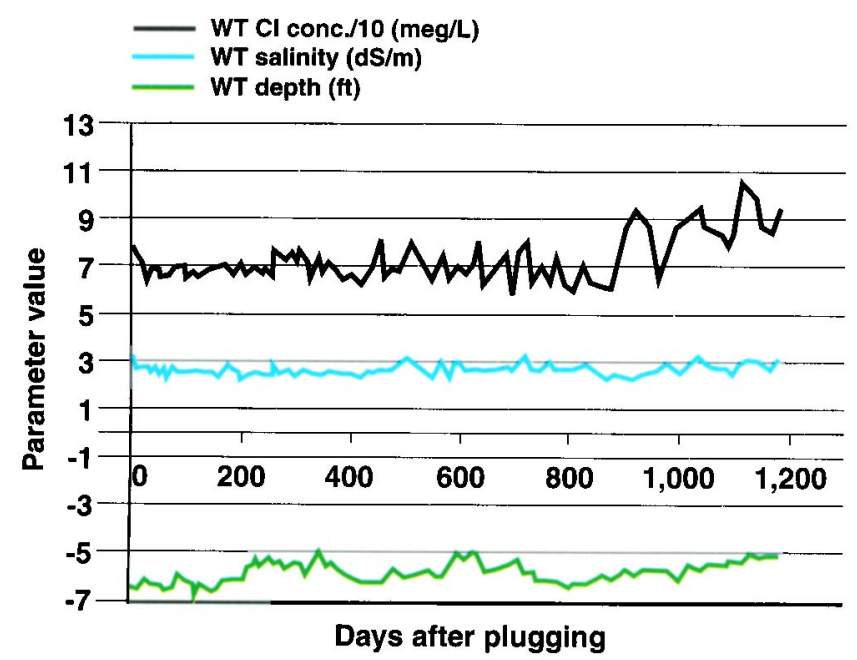

Fig. 2. Area 80 water-table levels, salinity and chloride concentrations after plugging subsurface drainage system. animal pens, respectively, while the intermediate

1,000-foot section continues to be farmed for a variety of truck crops and cotton. The subsurface drainage system was blocked via an access manhole to the eastern-most lateral drain collector junction, approximately 120 feet east of the IID ditch outlet. A west-east transect of 10-foot-deep PVC-cased observation wells was installed just south of the dairy cattle facility to monitor water-table levels and salinity.

Area 80 is a square field 1,250 ft on a side, or about 36 acres, to the northeast of Area 40 and just southeast of Area 70. It has loamytextured soils with mixed clay and loam soil layers. This layered profile also reaches depths in excess of 70 (approximately 1 mile). Area 40 has clay loam soils with profile depths of at least 10 feet and one of the oldest drainage systems on the DREC, comprising five 1,450-foot-long, 6-inchdiameter concrete drain laterals on a 120-foot spacing installed prior to 1955. The laterals run south to north on a rectangular grid system into a west-east concrete collector drain that discharges into the district drainage ditch immediately to the east of Area 40.

Currently, the southern and northern approximately 250 feet of this area are covered by the relatively new Extension Service building at the DREC and the older dairy cattle feed mill and
$3 \mathrm{~m}$, but appears to be interfingered with sandier layers connected to the fine-sand aquifer that surfaces in Area 90 just to the north of Area 80. The Area 80 drainage system, installed in 1967 , is composed of nine diagonally oriented 4-inch-diameter concrete laterals on a 150 -foot spacing, draining to the northeast into an 8-inch-diameter concrete collector line. The collector line from Area 80 joins one for Area 90 and eventually discharges into a sump and into the district drainage ditch located at the northeast corner of Area 90 and the DREC.

The subsurface drainage system was blocked at an access manhole to the eastern-most lateral drain and collector junction. A south-north transect of 10-foot -deep PVC-cased observation wells was installed along the eastern side of Area 80 to monitor watertable levels and salinity. Water-table levels and salinity measured in this transect were corroborated by similar measurements taken from a grid of observation wells located in Area 80. We also monitored the water levels and salinity in the manhole at which the drainage system was blocked.

Water-table levels were manually measured in the observation wells using a steel tape on the day the drain was plugged and at intervals of 4 to 21 days after plugging the drainage systems (Aug. 23, 1994). Following measurement of the groundwater level, we collected water samples using a handheld vacuum pump with a silt trap for later analysis in the DREC laboratory of electrical conductivity (EC), reported here as salinity, and chloride concentration. EC measurements were made using a standard conductivity cell coupled to a standard electrical bridge. Chloride concentrations were determined using an Aminco chloride titrator.

Areas 40 and 80 are divided into subareas (for example, 41-42, 81-82 and so on) or fields according to specific cultural practices and cropping, depending on the needs of the different researchers working on the DREC. Table 1 summarizes the crops on these fields during the past 4-year period of blocked subsurface drainage. Although irrigation dates were available for Area 80 from our other studies related to water conservation potential with forage crops, reliable irrigation dates in Area 40 were not available. However, we noted in the field that watertable levels responded immediately following any surface irrigation event in an area. Generally, for the forage crops grown in these areas, irrigation events occurred every 7 to 14 days during the summer season (May through September) and roughly monthly during the remainder of the year.

\section{No rise in salinity, chlorides}

Considering that more than 30 years of artificial drainage had occurred in Areas 40 and 80, we had ex- 


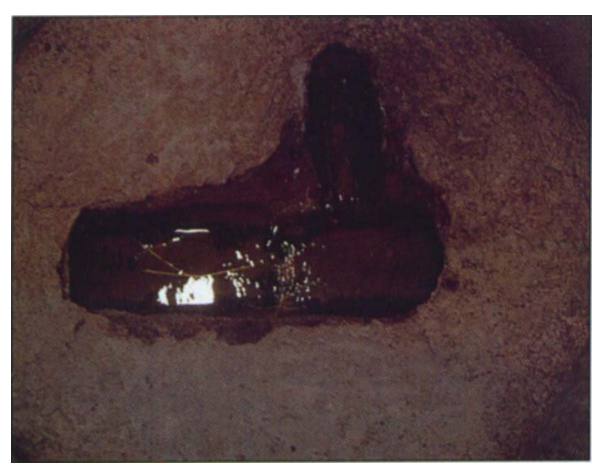

Scientists blocked the drains at junctions, like the one shown above, to observe the effect on salinity and water-table depth in heavy soils in the Imperial Valley.

pected to see a gradual rise in watertable levels, groundwater salinity and groundwater chloride concentration due to the addition of irrigation water to the system when this drainage outlet was blocked. This expectation was based in part on the experience of the Broadview and Westlands Water Districts in the San Joaquin Valley. Following blockage of drainage systems in parts of these districts, groundwater levels tended to rise and soil salinity increased. However, our experience at the DREC had been that the IID deep drainage ditches, combined with the presence of a shallow fine-sand aquifer below the DREC, controlled shallow groundwater levels below the DREC to a greater degree than the field drains.

After over 3 years of monitoring, we found that average water-table levels in Areas 40 and 80 followed a seasonal variation that reflected the frequency of irrigation (and, to a lesser degree, the ET variation). Similarly, salinity and chloride concentrations were variable, but remained roughly constant (figs. 1 and 2, respectively). With the exception of this past year,

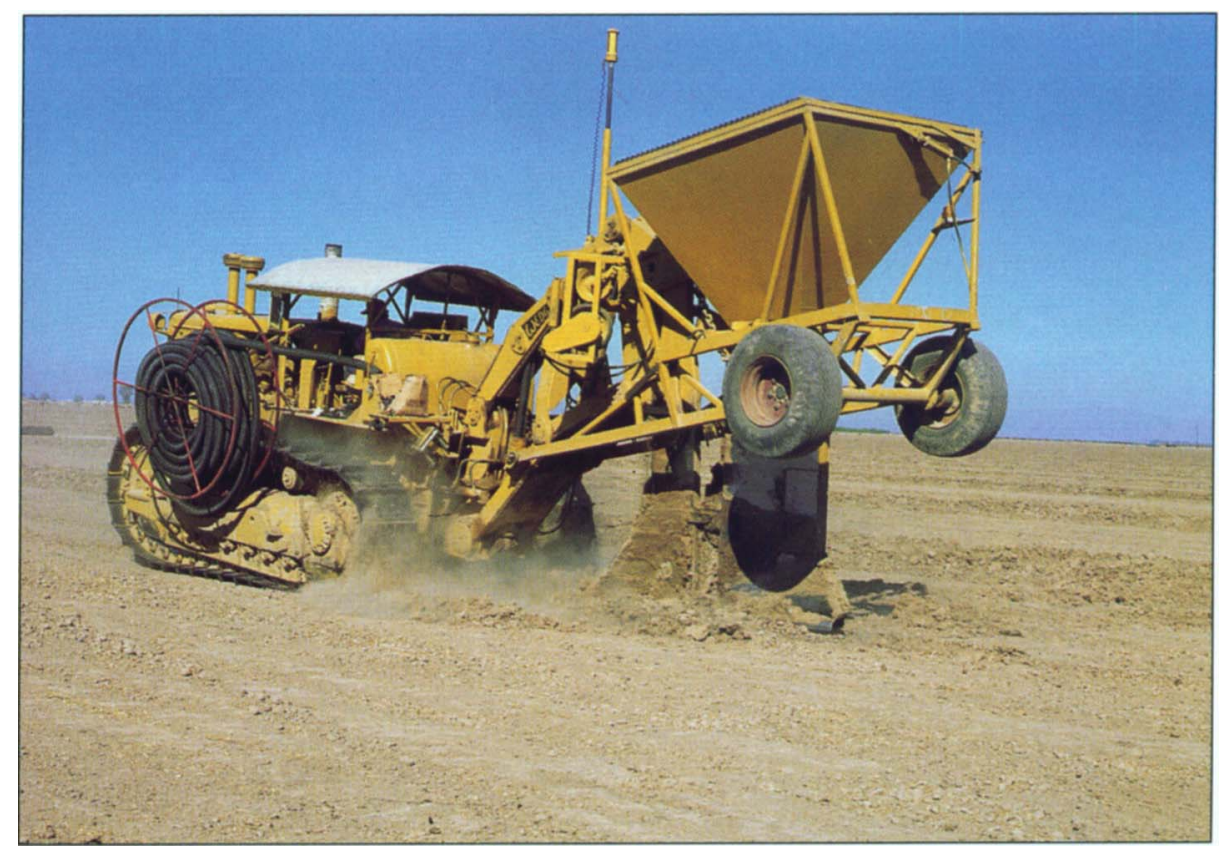

Replacement of old clay and bituminous fiber drains with new plastic drains only increased drain flow rates, rather than improved drainage of the field.

when irrigation frequency increased, there are no increasing trends in the water-table levels, salinity or chloride concentrations; that is, the mean value of these parameters has not changed significantly with elapsed time since blocking the drains. Water-table levels show a sustained rise when irrigation is relatively frequent during the summer months (for example, days 230 through 400 and 600 through 750 ) and decline during short, nonirrigated periods associated with crop rotation or harvesting. Average salinity and chloride concentration in Area 80 are less than those for Area 40 due to the more highly permeable soils in Area 80, which facilitate greater leaching. Similarly, average salinity and chloride concentration in the drainage ditch adjacent to Area $80(5.8 \mathrm{dS} / \mathrm{m}$ and 22.4 meq / $\mathrm{L}$ respectively) were less than that for Area $40(6.5 \mathrm{dS} / \mathrm{m}$ and 24.8 meq/L respectively).
We also expected to find an approximate correlation between watertable levels and groundwater salinity and chloride concentrations. As watertable levels rise due to comparatively good-quality irrigation water reaching the shallow groundwater, we expected groundwater salinity and chloride concentrations to decrease. However, no statistically significant correlation between water-table levels and either water-quality parameter exists for the data sets for either area. In fact, the most recent chloride concentration data for Area 80 show an increasing trend that appears to be associated with increasing concentrations in the IID drainage ditch adjacent to the area. Lack of correlation could be due to the increased salinity of irrigation water as it leached the soil profile so that it became similar in quality to that of the groundwater. Or it could be that in the time between individual measure-

TABLE 1. Cropping patterns and planting dates for Areas 40 and 80 of the DREC,1994-1998

\begin{tabular}{|c|c|c|c|c|c|c|c|c|c|c|}
\hline \multirow[b]{2}{*}{ Area } & \multicolumn{2}{|c|}{1994} & \multicolumn{2}{|c|}{1995} & \multicolumn{2}{|c|}{1996} & \multicolumn{2}{|c|}{1997} & \multicolumn{2}{|l|}{1998} \\
\hline & Crop & Planted & Crop & Planted & Crop & Planted & Crop & Planted & Crop & Planted \\
\hline Subarea 41-42 & Sudan & $4 / 1$ & Cotton & $3 / 15$ & Cotton & $3 / 15$ & Cotton & $3 / 15$ & Cotton & $3 / 15$ \\
\hline Subarea $43-44$ & Cotton & $3 / 15$ & Sudan & $4 / 1$ & Vegetables & $3 / 1$ & Vegetables & $2 / 1$ & Vegetables & $2 / 1$ \\
\hline Subarea $81-82$ & Alfalfa & $10 / 20$ & Sudan & $3 / 15$ & Sudan & $3 / 15$ & Fallow & & Fallow & \\
\hline Subarea $83-84$ & Sudan & $3 / 15$ & Alfalfa & $10 / 15$ & Alfalta & cont. & Alfalfa & cont. & Alfalfa & cont. \\
\hline Subarea $85-86$ & Alfalfa & $10 / 15 / 91$ & Sudan & $3 / 15$ & Sudan & $3 / 15$ & Fallow & & Fallow & \\
\hline Subarea 87 & Orchard & $11 / 15 / 86$ & Orchard & cont. & Sudan & $3 / 1$ & Sudan & $4 / 1$ & Sudan & $4 / 1$ \\
\hline Subarea 88 & Alfalfa & $10 / 15 / 93$ & Alfalfa & cont. & Artichokes & $10 / 1 / 95$ & Sudan & $3 / 15$ & Sudan & $3 / 15$ \\
\hline
\end{tabular}




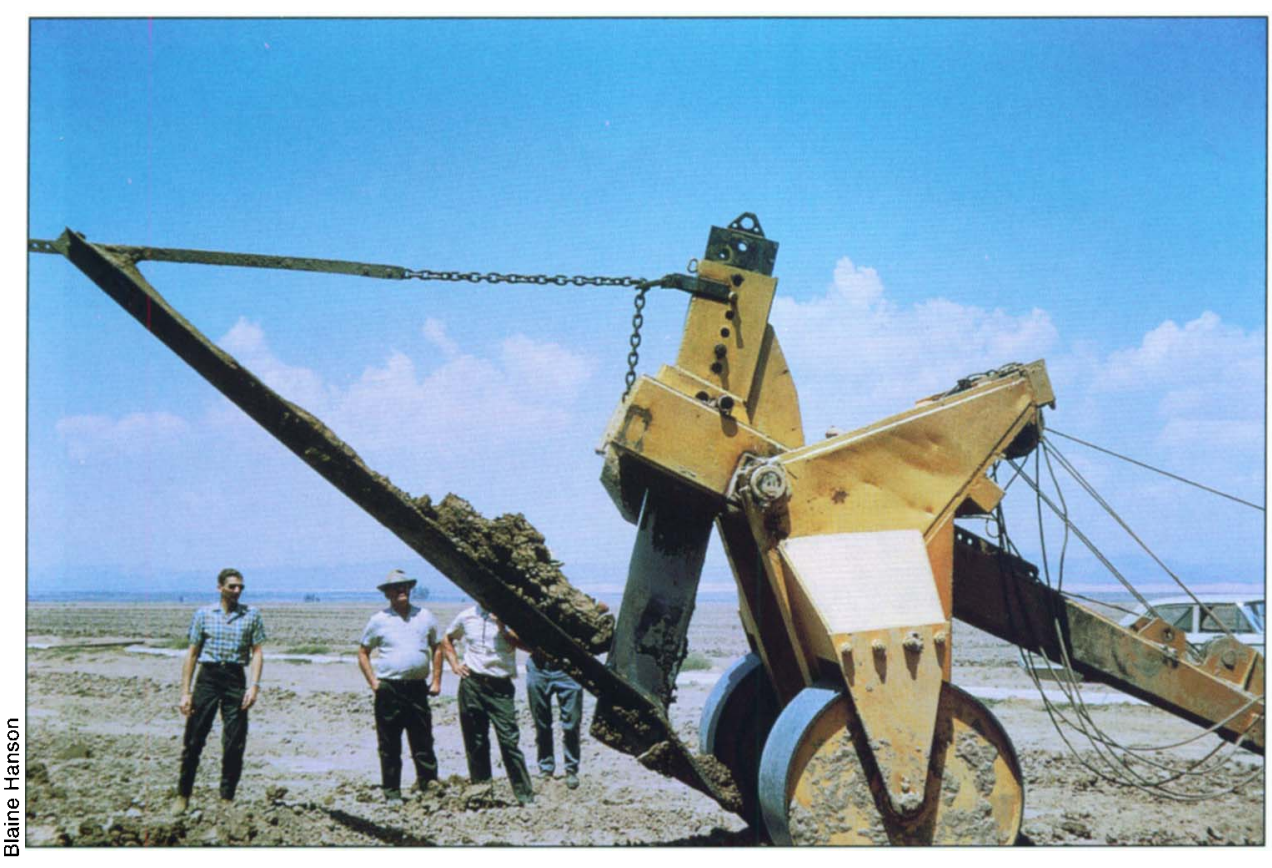

Deep ripping clay soils to improve water penetration and subsequent salt leaching, may be more cost effective than augmenting an existing subsurface drainage system.

ments (days to weeks), shallow groundwater flows had already assimilated the additional salinity so that little long-term increases are measured.

Although there appeared to be little overall change, we noted that plugging the drainage systems did in fact result in an increase in subsurface drainage system manhole water levels for Area 80 . These water levels followed a similar pattern with time to that for the Area 80 water table shown in figure 2. However, even in the manhole, water salinity remained more or less constant, and mean salinity and chloride concentrations did not increase in the time elapsed since plugging the drainage system.

Based on our field measurements, it appears that the DREC soils have sufficient natural drainage under the present hydrogeologic regime, despite being clay soils, so that the lateral subsurface field drainage systems are unnecessary, and any further augmentation of these systems would not be justified in terms of water table or salinity control. We were concerned, however, that short-term high watertable conditions resulting from irrigation that would not otherwise occur, because the artificial drainage system allows this high water table to "drain out" more quickly, would be detrimental to crops. It appears, however, that given the satisfactory or betterthan-average yields obtained for the variety of crops grown in Areas 40 and 80 (table 1), this concern is not an issue at the DREC. Finally, it may be more cost effective, in terms of soil salinity control, to deep rip the clay soils at the DREC to improve water penetration and subsequent salt leaching, rather than augment the existing subsurface drainage system. We base this suggestion on our observations of improved leaching and soil salinity conditions in the back-filled trenches associated with installation of the drainage system laterals.

\section{Artificial drainage ineffective}

Lateral subsurface drainage systems are often installed in irrigated regions to control soil and groundwater salinity and to keep it from having a detrimental influence on crop production. In the Imperial Valley, field drainage systems were installed throughout the region following construction of the deep-ditch drainage system by the Imperial Irrigation District, apparently without consideration of local hydrogeologic conditions that vary from field to field. At the UC DREC, we found that a shallow finesand aquifer underlying the DREC originally identified by Donnan and Blaney (1954), combined with the Imperial Irrigation District deep-ditch system, provided sufficient drainage relief for several areas of the DREC to successfully grow a variety of crops. That is, the water table and soil salinity levels in the field were more controlled by the shallow aquifer and IID drainage ditches than by the artificial subsurface drainage system. Given demonstration of the lack of effectiveness of subsurface drainage systems in three different fields that have soil characteristics similar to more than half of the valley soils, we expect that in many parts of the valley, augmentation of subsurface drainage systems through "splitting" the lateral spacing may not be warranted. Indeed, efforts to reduce the soil salinity of the heavier soils on the DREC, or elsewhere in the valley, may be better directed at improving water penetration and leaching of the soils through deep ripping or other cultivation/mulching methods, rather than expending resources on improving the subsurface drainage system.

M.E. Grismer is Professor, Land, Air and Water Resources-Hydrology and Biological and Agricultural Engineering, UC Davis, and K.M. Bali is Extension Advisor, UC Desert Research and Extension Center, Holtville.

\section{References}

Ayars JE, Grismer ME, Guitjens JC. 1997 Water quality as a design criteria in irrigation and drainage water management systems. ASCE J of Irr and Drainage Engr 123(3): 154-8.

Donnan WW, Blaney HF. 1954. Drainage investigation in the Imperial Valley, CA: 1941 1951 (A ten-year summary). Report No. SCSTP-120. USDA, Washington, DC

Grismer ME, Bali KM. 1997. Continuous ponding and shallow aquifer pumping leaches salts in clay soils. Cal Ag 51(3):34-7.

Grismer ME, Gates TK. 1988. Estimating saline water table contributions to cotton water use. Cal Ag 42(2):23-4.

Grismer ME, Tod IC, Robinson FE. 1988. Subsurface drainage system performance after 20 years of operation in the Imperial Valley. Cal Ag 42(3):24-5.

Grismer ME, Tod IC. 1991. Drainage of clay overlying an artesian aquifer:

I. Hydrologic Assessment. ASCE J of Irr and Drainage Engr 117(2):555-70.

Tod IC, Grismer ME. 1991. Drainage of clay overlying an artesian aquifer: II. Technical Analysis. ASCE J of Irr and Drainage Engr 117(2):571-84.

Yusufzai AK, Grismer ME. 1994. Vertical drainage may improve soil salinity. $\mathrm{Cal} \mathrm{Ag}$ 49(2):12-5. 